\title{
Public perception of urban identity in post-Soviet city: the case of Vinnytsia, Ukraine
}

\author{
Anatoliy MELNYCHUK ${ }^{1}$ and Oleksiy GNATIUK ${ }^{1}$
}

\begin{abstract}
This study deals with urban identity in Vinnytsia, one of the most economically vibrant Ukrainian cities, arguably known as a fiefdom of key Ukrainian power holders since the Euromaidan. Assuming that urban space may be treated simultaneously as a mirror and a factor of urban identity, the authors tried to look at urban identity under the lens of urban space transformations. The sociological survey conducted in 2016 and covering 168 respondents was focused on public representations about the city in whole and particular places in the city as well, including important recent changes of urban landscape. We came to conclusion that Vinnytsia represents an inclusive model of urban identity growing from additional actualized strata of historical memory. However, there is a stable core of identity, requiring a great deal of effort to be changed. We confirmed our hypothesis that identity-related discussions in Vinnytsia are centred on the issue of leadership, caused by current privileged position of the city and successful municipal reforms implemented by the local administration, and the issue of modernization, including aggressive commercialization, threating the historic urban landscape. The survey revealed the re-assessment of the role of industry as an element of local identity and demonstrated that the public requirements to the urban space experienced a strong shift towards human-friendliness, aesthetics, safety and diversity instead of political or ideological symbols. We observed pronounced shift to the local and regional values, although the connection with the national identity remains important. Finally, we came to conclusion that the success of transformation is largely defined by the possibility to painlessly combine new senses and connotations of places with the already existing. Thus, local identity may be considered as one of the key factors determining the perception of the urban space transformation, making urban landscape more resilient to the possible harmful impendences.
\end{abstract}

Keywords: urban identity, transformations, urban space, urban landscape, post-socialist city, Vinnytsia, Ukraine

\section{Introduction}

Cities under the Soviet rule were designed to glorify the ideas of communism. Subsequently, the authorities made all possible efforts to construct relevant urban identities: some aspects of already existing identities were artificially enhanced, other, on the contrary, silenced or completely erased. Nowadays, with a fall of communism, cities are once again rethinking their identities. This process is problematic and often contradictory, as it takes place under political, cultural and economic transition (SÝKORA, L. 2009) and involves different actors like globalization process, national and re- gional governments, city administration, urban activists and ordinary citizens (HeIn, C. 2012; Roșu, L. 2015).

The identity formation process implicates selection generalization and reinterpretation of history, including both tangible and intangible heritage, by multiple actors according to their goals (SEMIAN, M. and NováčEK, A. 2017). The ideological and political shift put into question the meaning of urban public spaces as an instrument for building local and national memories and identities (Molnár, V. 2013). Young, C. and Light, D. (2001), as well as Young, C. and KaczmareK, S. (2008) point at three possible and poten-

\footnotetext{
${ }^{1}$ Department of Economic and Social Geography, Taras Shevchenko National University of Kyiv, vul. Volodymyrska 60, Kyiv, Ukraine. E-mails: melan97@ukr.net, alexgnat22@ukr.net
} 
tially coexisting scenarios of modern identity building in different post-socialist cities, each shaped by different national contexts of the experience of socialism and post-socialism: they may (1) draw on pre-socialist "Golden Ages" as their key source of identity and seek to obscure the socialist period, or (2) draw on the history of the socialist period but utilize it more as a part of emphasizing their anti-communist credentials, or (3) may actively include some elements socialist past in highly contested ways in their contemporary identity formation. Anyway, the idea to enhance the "Europeanness" is in general use among post-socialist cities in different countries (McNeill, D. and Tewdwr-Jones, M. 2002; Gospodini, A. 2004; Young, C. and KaczmareK, S. 2008).

Urban identity building reflects also interaction between hierarchical levels of territorial identity, which often is well-accentuated in post-socialist societies. JANSEN, S. (2001) and Zechenter, K. (2015) suggested that the symbolic success of post-socialist cities depends on aligning the city's identity with the general prevalent understanding of national identity. However, there is evidence that in post-socialist countries local urban identity, due to some reason, may run counter to the national identity, as it happened in Sevastopol before the annexation of Crimea (Qualls, K.D. 2009) and in post-Milosevic Belgrade (Volcic, Z. 2005). The representations of four Ukrainian cities in fictional narratives by contemporary authors show underscored sense of belonging to the local territory, yet the sense of belonging to the nation and the world is not dismissed (Rewakowicz, M.G. 2010).

Urban space may be treated simultaneously as a mirror of existing urban identity and as a factor of its development. This statement is widely supported in literature (KARAMAN, A. 2001; Stobart, J. 2004; BARIS, M.E. et al. 2009). Urban landscape, seen by people every day, shapes their representations about the city and simultaneously reflects both spontaneous and deliberately constructed changes in identity, making visible the interactions (including contestation) of different actors and stakeholders. The public attitudes to the certain changes in urban landscape often display hidden or low-observable aspects of local identity development. The transformation of meaning, together with the use and attitude toward landscape, has become visible due to spatial and functional manifestations of post-socialist cities (CZEPCZYŃsKI, M. and Sooväli-Sepping, H. 2016). Diener, A.C. and Hagen, J. (2013) argue that varied and often competing economic, cultural, and political forces are narrating the new national identity through urban space. This is especially true for historical urban space (AzARYAHU, M. and Fооте, K.E. 2008). Political elites are engaged in a symbolic dialogue with each other and with the public through both physical transformations and "commemorative maintenance" of monuments having high symbolic value (Forest, B. 2002; BurCh, S. and Smith, D.J. 2007; Adams, J.S. 2008). According to Ter-Ghazaryan, D.K. (2013), the transformation of prominent places represents the vision of elites but simultaneously often receives a critical voice from the local residents. Moreover, the attempts to reconstruct important monuments of the past often can generate a contestation of the same past they are intended to cement (AlEKSANDRAvičius, E. 2006; Haskins, E.V. 2009). Simultaneously, the socioeconomic changes reflected in housing stock, structure of land use, etc. also contribute to changing urban identity (BATER, J.H. et al. 1998). However, we should take in mind that the landscape of post-socialist city often represents a mix of socialist urban fabric and capitalist forms fitted into it (DingsDale, A. 1999), which exacerbates conflicts between related senses of place.

Numerous studies (Kavaratzis, M. and Ashworth, G.J. 2005; Insch, A. and Florek, M. 2010; Mohapatra, B. and RazaK, A. 2013; Kavaratzis, M. and НатсH, M.J. 2013; RiusUlldemolins, J. and Jiménez, L.P. 2016; AgboolA, O.P. 2017) point out that strong identity makes urban community more consolidated and resilient to internal and external challenges and helps to create an attractive 
image of the city for tourists and investors. The stronger is local identity, the more actively residents participate in forming their surroundings, in maintaining the built cultural heritage and in negotiating the development of their city (PAP, A. 2014). This is specifically true for post-socialist cities in their search for own unique character in order to increase the competitiveness (Young, C. and KaCZMAREK, S. 2008; Октау, D. and Bala, H.A. 2015).

To extend our knowledge about the relationship between urban space and post-socialist identity formation, especially given the lack of relevant studies in post-Soviet space, we decided to have a closer look on the Ukrainian city having two essential characteristics. First, it should be typical and representative case in terms of historical heritage, industrial development, tourism potential, level of symbolical penetration of socialism into the urban landscape, etc. Second, it should have sufficiently intense pace of both post-socialist identity building and transformation of urban space. Having such a research subject, we focused on the following aspects:

1. Applicability of previously known postsocialist strategies and patterns of urban identity building in transition to the typical post-Soviet city.

2. Conflict between the new history-driven and globalization-driven elements of identity.

3. Relationships between local, national and supra-national identities in post-Soviet urban identity building.

Being convinced in the feasibility of a holistic approach to the study of urban identity (Октау, D. and Bala, H.A. 2015), we performed pre-analysis of the urban environment of chosen case city followed by sociologic survey of the inhabitants.

\section{City of Vinnytsia as a case}

In this study we focused on the city of Vinnytsia, located in the south-western Ukraine on the banks of the Southern Bug River, administrative capital of the homonymic region, the largest city $(373,000)$ within the historical region of Podolia, pretending to be its informal capital. Since the first mention in written sources (1363), it belonged to the Grand Duchy of Lithuania (until 1565), Polish-Lithuanian Commonwealth (1565-1792), Russian Empire (1792-1917), Ukrainian People's Republic (1917-1920), the Soviet Union (1920-1991), and independent Ukraine (since 1991). Such comprehensive history has determined heterogeneity of the urban landscape and historical memories that could be actualised in local identity.

Since the Soviet Union collapse, the city's economy experiences transition from industrial to post-industrial one, characterized by decline in traditional industry (first of all precision machinery) and burst in tertiary sector (predominantly retail, but also IT-sector and tourism). The current Strategy 2020 for the city development contains numerous emphases on the regional leadership of Vinnytsia in Podolia and all central Ukraine.

Since 2014, Vinnytsia turned into an economic and political domain of key current Ukrainian power holders. In particular, Volodymyr Groysman, Ukrainian Prime-Minister since 2016, was a Mayor of Vinnytsia between 2006 and 2014; he managed to implement a series of successful municipal reforms, which brought Vinnytsia to the top of Ukrainian urban ratings. In particular, it was twice (in 2013 and 2015) recognized as the best city for life in Ukraine. Petro Poroshenko, Ukrainian President since 2014, several times was elected a parliamentarian precisely in the local electoral constituency and has business interests in the city, including two Roshen confectionary factories. The Roshen Light-Musical Fountain, which started to give performances in 2011 and became the most famous local tourist attraction, was constructed at the expense of the Poroshenko's Charity Foundation.

Nowadays Vinnytsia, being one of the most economically affluent Ukrainian cities, experiences rapid changes of urban landscape, including renovation of historical architectural heritage, new housing construction; substitution of traditional markets and 
pop-up retail with modern shopping malls, boom of street-art, as well as modern forms of urban greening and landscape design. However, aggressive commercialization often threatens the historical legacy of the city, causing numerous urban planning conflicts.

Vinnytsia is a city where different actors are making clearly expressed attempts to promote local urban identity. In the Soviet epoch, the city was associated primarily with two tourist attractions: the Werwolf, Hitler's headquarters, and the museum-estate of the prominent surgeon Nikolai Pirogov. The city was also known as "Small Kyiv" (for similar hilly terrain along the riverside) and "Capital of Sugar Donbas" (surrounding region was the main producer of sugar beet in the USSR). Since the 2000s, numerous attempts have been made to restore memory of those historical epochs that were consciously silenced in Soviet times. This is, first of all, so-called "Silver Age of Optimism", a period of rapid development of the city of the late $19^{\text {th }}$ and early $20^{\text {th }}$ centuries, when the ordinary district town quickly turned into a powerful regional centre. In particular, the last decade was marked by a mass campaign, started by local history experts and taken up by the city administration, popularizing the legacy of Hryhoriy Artynov, a chief city architect in 1900-1919, who had factually designed the architectural face of the modern city centre. Another actualized historical period was the Ukrainian struggle for the independence (1917-1922) when Vinnytsia twice (in February and March of 1919 and in May and June of 1920) was the temporary capital of the Ukrainian People's Republic. Also, the city is increasingly mentioned as an important military-administrative centre of the Cossack times. The memory and ideas of these historical epochs are widely used while celebrating the main annual city holidays - the City Day and the Europe Day. This appeal to the history is reflected in the urban landscape by means of renaming the streets, establishment of monuments, opening thematic museums, etc.

\section{Methodology}

The survey of inhabitants was conducted in April-May 2016 and embraced 168 respondents. Only local residents permanently living in the city at least for the last 5 years were eligible. The sample was representative in terms of sex and age structure. A questionnaire contained a set of questions targeted at respondents' opinion on the urban space transformation, as well as their ideas and representations about the city. The design of the questionnaire was based on the elaborations of Gospodini, A. 2004, BARIS, M.E. et al. 2009, SABAN ÖKESLI, D. and GÜrçINAR, Y. 2012, van Der Lugt, R. 2013, OKtay, D. and BALA, H.A. 2015, as well as on the previous experience of the authors in studying urban identity. Also, we reckoned with some previous results (MeLnychuK, A. et al. 2013) describing key challenges of the selected city transformation.

We used the following set of questions:

1. What are the symbols of your city? [open-ended; up to 3 options].

2. How does the urban space have changed? [open-ended].

3. How did the latest architectural and planning innovations change the face of the city? [4 answer options - see Figure 1].

4 . What does the city need? [5 answer options - see Figure 3]

5. How appropriate do you consider the following transformations of urban landscape? [14 answer options - see Figure 4; the respondents had to rate each case using the following scale: +2 (very appropriate), +1 (quite appropriate), 0 (indifferent, has the right to exist), -1 (bad), -2 (unacceptable)].

6. What does the city means for you? [10 answer options - see Figure 5; the respondents had to set up priorities from the most (10 points) to the least (1 point) important].

7. What is your attitude to the statement that Vinnytsia is a provincial city? [5 answer options: A. Negative: Vinnytsia is really not quite a big city, but provincialism is measured rather by the way of thinking and living then the number of population; B. Positive: Vinnytsia 
is a relatively quiet, cosy, compact city with good environmental conditions; C. Vinnytsia is quite a small but upcoming city, which, however, evolve to get rid of provincialism; D. Negative: Vinnytsia is a great progressive European city that cannot be called provincial; E. Positive: Vinnytsia is a grey and dirty city with a lack of opportunities but excessively high ambitions of local administration].

8 . Who should be memorialized in the city (in the form of monuments, street names, etc.)? [5 answer options: A. prominent locals; B. prominent people related to Vinnytsia; C. prominent Ukrainians; D. fighters for freedom and independence of Ukraine; E. outstanding figures of the world history and culture].

9. How the following actors (neighbours, relatives and friends, local history experts, local authorities, NGOs) have influenced your attitude to the city in recent times? [ 3 answer options for each of the actors: A. positively; B. neutrally; C. negatively].

10. After the installation of Roshen light-musical fountain, Vinnytsia is: [2 answer options: A. city with a fountain; B. city near a fountain). Ranges, medians and quartiles for questions with ranking and score evaluations were calculated using Statistica 9.0 analytics software package. The answers to the openended Question \# 2 were processed to identify the main semantic ideas, which were visually represented using tag cloud technique.

\section{Survey results and discussion}

Respondents indicated 20 landmarks as urban symbols. The shortlist of 5 landmarks, mentioned by more than 10 per cent of respondents, includes 4 traditional symbols of the city belonging to different epochs (Tower of Vinnytsia - 73.5\%; Pirogov Museum - 44.6\%; Park Entrance Arch - 38.6\%; Complex of monasteries and fortifications, known as "The Murals of Vinnytsia" - 14.5\%) and only 1 modern symbol, Roshen Fountain (63.9\%), which has rapidly burst into a cohort of leaders. We have not found any statistically significant effect of modern reconstruction and renovation: this indicates that a clear hierarchy of urban symbols has been shaped in the city, which is difficult to change, and only media-promoted megaprojects could interfere with it.

Respondents believe that urban space has become more modern and comfortable; the most of new facilities have harmoniously supplemented the historical environment. However, approximately every fourth respondent pointed at destruction of the city's historical face spoiling local urban spirit; there is no public consensus regarding the profoundness of urban space changes (Figure 1).

Respondents believe that the city experiences intensive changes consisting in construction, renewal and renovation. The general direction of these changes is considered to be positive and is defined through the terms of improvement, progress, development, and beautification. Citizens believe urban space to become better, which means primarily - more modern, more attractive, more comfortable, and more European. The most often mentioned objects of changes were: urban infrastructure (in the context of modernization), historic buildings and monuments (in the context of renovation), and public spaces (in the context of beautification and improvement) (Figure 2).

The respondents have quite a consensus opinion about the overload of urban space with such post-socialist innovations as shopping malls. Although the majority of respondents give the greatest importance to the creation of new industrial facilities, it is necessary to emphasise a very large range of estimates. Rehabilitation and restoration of historic buildings and architectural monuments was recognized to be the second most important priority. Not much less importance is attached to improvement of public spaces and landscaping: these options had strong public support despite the fact that over the last decade the city's authorities have already done a great job in these areas (Figure 3).

The greatest public support was observed for the restoration of historical areas, monuments and public spaces without drastic changes to their visual appearance and func- 


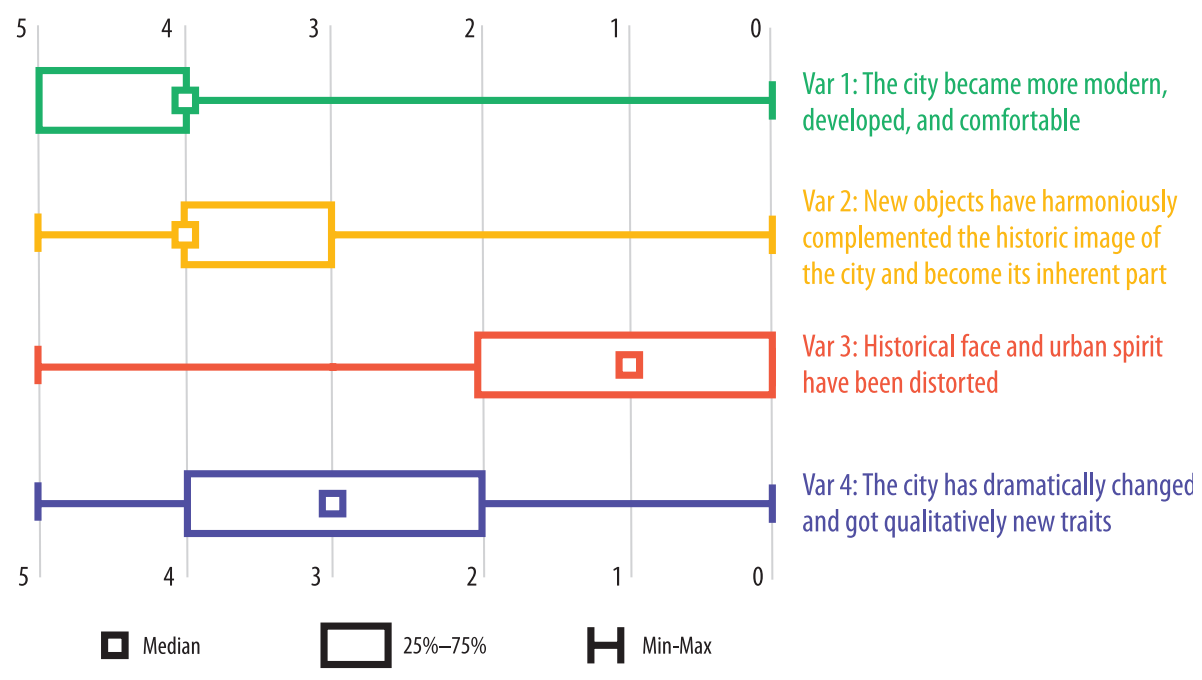

Fig. 1. How has the urban space changed?
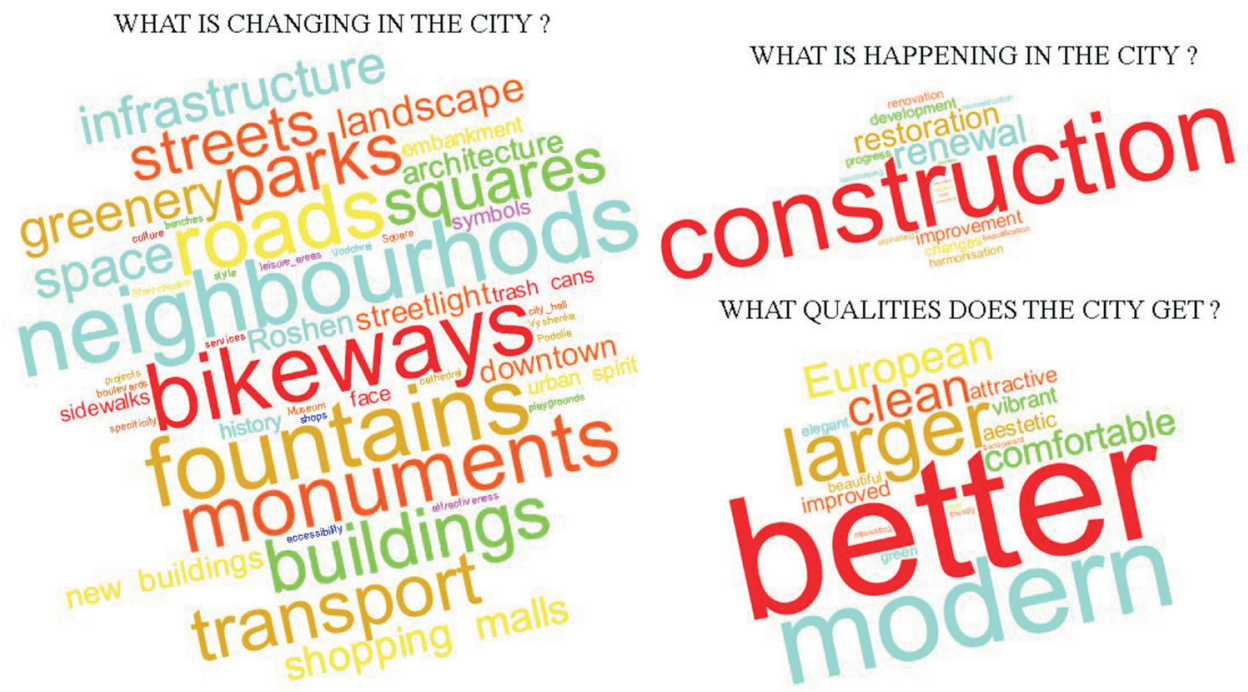

Fig. 2. Wordclouds reflecting frequency of ideas mentioned by the respondents

tionality, when the old senses and connotations of place are strengthened or combined with new ones without obvious contradiction in between (Figure 4). On the other hand, changes leading to the destruction of the old senses and causing aesthetic and/or functional conflict with already shaped urban landscape received the most unfavourable evaluations. The first example of such a situation is construction of the Cloud shopping 


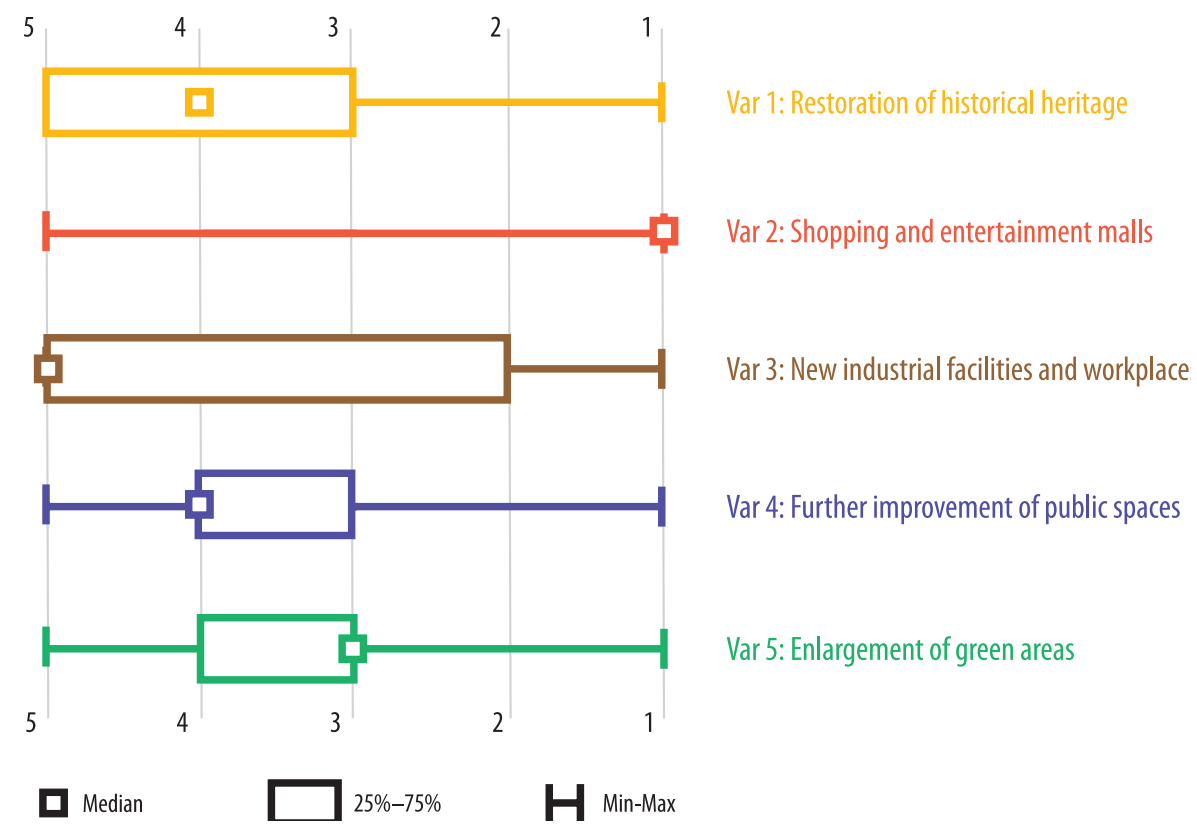

Fig. 3. What does Vinnytsia need?

mall in direct proximity to the Holy Virgin Cathedral, an architectural monument, dated back to 1745: two buildings are completely incompatible in terms of function and design. The second example is protracted reconstruction of the Gagarin Square that led to the total destruction of its previous appearance and made it similar to many other squares with underground shopping malls in different cities throughout the country. However, we should admit that respondents have general critical attitude to the construction of new shopping malls regardless of their harmonisation with the surrounding environment. Particularly comprehensive situation is observed when both old and new senses of place are historically legitimate and not imposed by administration or private business, but should compete with each other within the same place. Basically, this leads to a split of public opinion, as happened in the case of the Shevchenko monument at Teatralna Square. Since the beginning of the $20^{\text {th }}$ century, this place was informally known as "The
Paris of Vinnytsia" and nowadays is used as a place for jazz and rock festivals. Therefore, many citizens consider it incompatible with the figure of the Ukrainian canonical poet and artist. On the other hand, the square was a place where locals gathered during the Euromaidan, so the other part of respondents has strong assertion that Shevchenko as a national prophet and visionary of public unrest has every right to be memorialized there.

Changes, associated with the development of urban industrial base and infrastructure (e.g. construction of a new tram line), have relatively good public ratings. However, a negative effect caused by the links with political figures can be traced. In particular, construction of the second Roshen factory, linked to Poroshenko, received relatively poor assessments although it is a big employer, providing citizens with additional workplaces.

The public opinions on the city's provinciality were divided almost into halves: while 55 per cent of respondents believe that Vinnytsia is not a provincial city, the other 45 per cent 


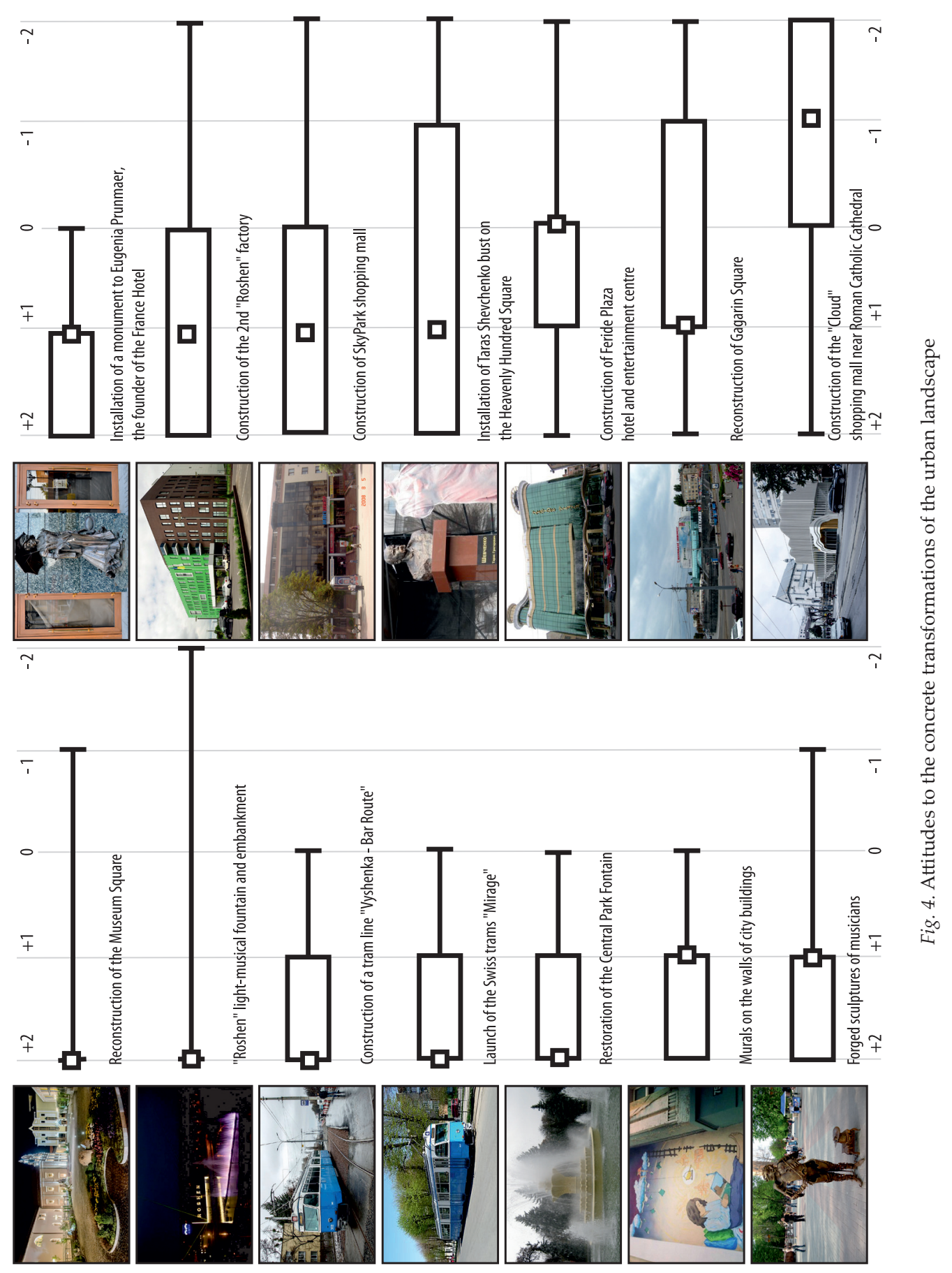


hold the opposite. However, more than 70 per cent of respondents believe provincialism to be negative value disrespecting the city and its residents. For the relative majority of respondents, provincialism is determined rather by local culture then the size and status of the city. Another large group of respondents believes provincialism to be advantage as it manifests itself through the calmness, quietness, compactness, and good environmental conditions. Every fifth resident believe the provinciality to be objective reality for Vinnytsia. However, nearly the same proportion of residents considers Vinnytsia to be a progressive and European city.

Regarding the priority of meanings and connotations, associated with the city, the following regularities are observed (Figure 5). First, senses reflecting local uniqueness ("City upon Bug River", "Place where Pirogov lived", "Kotsiubinsky Motherland") are more popular than those based on the similarity of Vinnytsia to other cities ("The Little Kyiv"). Second, it is important for the respondents to understand their city as advanced, leading and better over the others ("The best city in Ukraine", "The capital of Podolia"); on the contrary, connotations, referring to the relative inferiority of the city, including provinciality, have low priority ("The Little Kyiv", "The Golden Province"). Third, direct or indirect relationship with modern political or commercial figures has negative connotations: ideas of "Poroshenko's Motherland" and "Ukrainian Chocolate Capital" are clear outsiders.

Public opinions about preferences in commemoration are very symptomatic: more than 86 per cent of respondents think that commemorated people should have some relation to the city (including 31\% of respondents take the view that these should be locals born in Vinnytsia). This obviously indicates a shift toward local identity and the desire to make the city's landscape unique and different from the urban landscapes of other cities, dropping with the Soviet practice, when every city had a similar set of street names and memorials commemorating people having nothing common with a local context. However, this shift does not mean neglect-

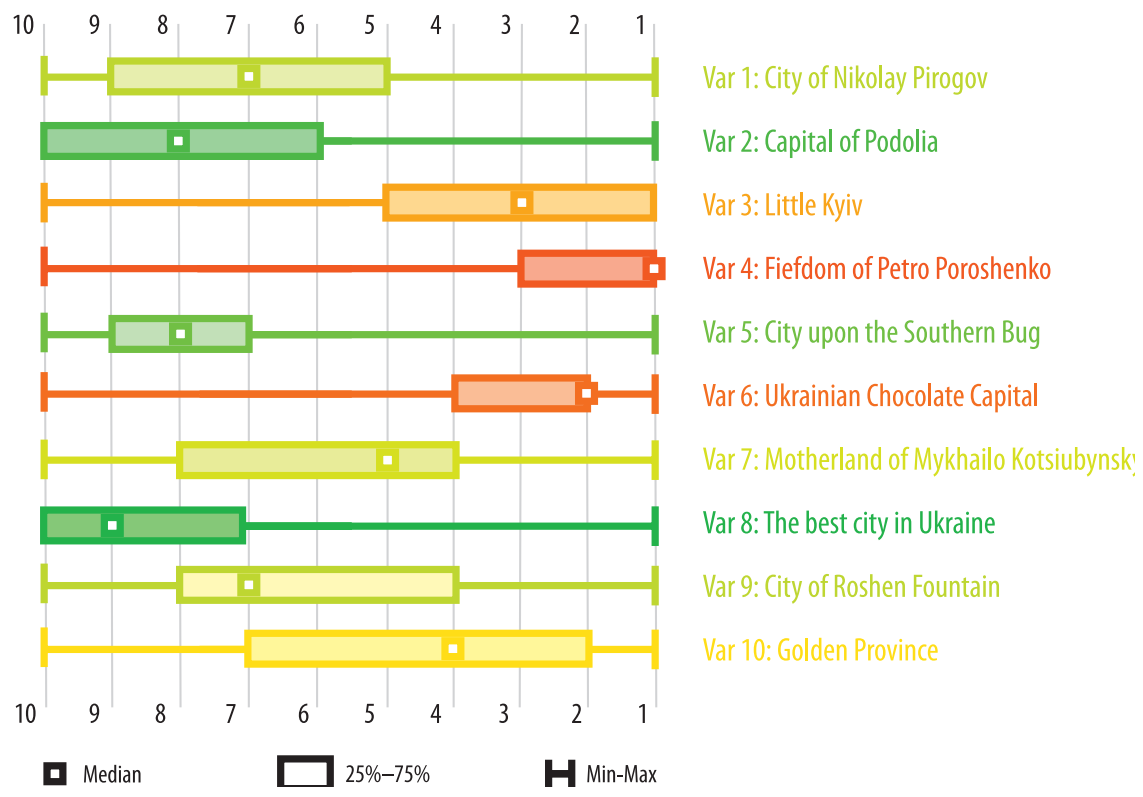

Fig. 5. Ranking of meanings and senses, associated with the city 
ing of national identity, as 36 per cent of respondents expressed in favour of fighters for Ukrainian freedom and independence.

Activities of the local history experts and the local authorities have the most positive influence on the public attitudes to the city. Interestingly, NGOs have the worst balance of positive and negative influence. This suggests that, firstly, civil society in Vinnytsia remains in the shadow of the local administration, which leads the process and finally win the laurels of reformers, and secondly, public willingness to distance from politics relates rather to state power holders than the local city administration, whose activities are perceived in a positive light. Finally, absolute majority of respondents consider Vinnytsia as a city with a fountain, and only 2 per cent think that the city is only an addition to this modern sightseeing.

Similar to the previous studies in field (OKtay, D. 1998; Bornberg, R. 2008; ОктAy, D. and BALA, H.A. 2015), the survey confirmed the importance of locally characteristic and identifiable natural landscape in shaping urban identity, as it represents one of the most stable major elements of identity and substantially contributes to the perceived quality of life. Simultaneously, new aesthetic of public spaces in the central part of the city, especially main squares, play special role in shaping new urban identity (STOBER, D. and Cavrić, B. 2014) and, as Boros, L. et al. (2016) emphasizes, their transformation often is accompanied by acute urban conflicts due to confrontation of different interests, ideologies and urban policies. Like in other cases (Young, C. and KaczmareK, S. 2008; Saban ÖKESLI, D. and GürçINAR, Y. 2012), the rediscovery, restoration and representation of the architectural heritage, as well as the regeneration of the cultural space, has been a key feature of post-socialist identity in Vinnytsia.

We can deem that in Vinnytsia, like in the other cities in Central and Eastern Europe, the identity transformation occurs under conditions of neo-liberalization, modernisation and globalisation, with specially pronounced role of so called "Europeanization", like it was in
Leipzig (Coles, T. 2003), Krakow (Hughes, H. et al. 2003), Warsaw (Crowley, D. 2003), Lodz (Young, C. and KaczmareK, S. 1999, 2008); Iași (Roșu, L. 2015). This “Europeanization" consists in promotion of European art, culture and values, including multiculturalism, by means of changing architectural appearance of the city and such public events as mass celebrations. The elements of the "unwanted socialist past" (see Young, C. and KaczmareK, S. 2008) are preserved but obscured or, at least, not specially emphasised. There is also typical common reference to the idealized "Golden Age" of the city development, as in Warsaw (CzARniawsKa, B. 2002), Lodz (Young, C. and KaczmareK, S. 1999, 2008), Leipzig (Coles, T. 2003), Mostar (Grodach, C. 2002), Novgorod (Petro, N.N. 2005), Banská Bystrica (Bitusıkova, A. 1998), Tallinn (Hackmann, J. 2005), Odessa (Gubar, O. and Herlihy, P. 2005), etc.

Like in many other post-socialist cities, in our case study the modern identity at large pushes traditional industry to the back and relies on postindustrial image stressing the development of the service sector (including leisure, tourism, and art) and high-tech industries (MAdsen, H. 1992; Wilkinson, S. 1992; ShorT, J.R. et al. 1993; PADDison, R. 1993; Noworol, A. 1997; Waskiewicz, J. and Bogacz, T. 1997; Young, C. and Lever, J. 1997; Grifiths, R. 1998). Nowadays, industry as such is no longer considered as evidence of the city's economic power and is not a reason for pride: now it has a subordinated position in the hierarchy of values and should not interfere with the realization of the main value - a high quality of life. However, the survey reflects certain reassessment of the industry and its importance for both urban identity and economy, which stands in line with suggestions that some identity elements may resists forgetting, although are officially disregarded (ADLER, N. 2005; Young, C. and KaczmareK, S. 2008).

Our study supports the conclusions of SABAN ÖKESLI, D. and GürçINAR, Y. (2012) that high consciousness about the history and identity of the city really contributes to the high quality of the urban environment. Since 
modern identity building in Vinnytsia is drastically based on the senses associated with the historical urban architecture, residents of Vinnytsia reckon the aggressive commercialization as the main threat to the integrity of the historical urban landscape and, accordingly, urban identity. This is probably an additional reason why new facilities for leisure and entertainment, like shopping malls, at the moment have not received important symbolical value, although they have substantially changed the visual appearance of the city and altered the way of public entertainment, which is similar to the findings from other national urban contexts (e.g. BARIS, M.E. et al. 2009). Simultaneously, since the idea of development and progress has become one of the fundamentals of the new urban identity, constant new construction is perceived as a necessary condition for the existence of the city. It gives the administration and business the opportunity to manipulate with public opinion in the implementation of their own projects, appealing to meet this request for constant development. However, as we see from the attitudes to the concept of provinciality, the pathos of modernization, intrinsic for some part of population, is balanced by the aspirations of another part to preserve the existing urban landscape. The overwhelming majority of inhabitants appreciate much the status of the city as a developed and perspective, but everyone understands this progress in its own way; however, the priority is the development of local urban culture and the preservation of the optimal size of the city to ensure a high quality of life.

The specific role of Vinnytsia as a domain of current Ukrainian chief power holders, as well as successful reforms implemented in the city, have affected the local urban identity in a dual fashion. On the one hand, citizens of Vinnytsia have developed a kind of superiority over the others, as they have had been continuously taught that their city is better, more progressive and more successful than others, and now it is important for them to keep the same feeling (KRYLOV, M.P. 2010). Also, the city pretends to be a regional leader, trying to enter a cohort of a top of influential Ukrainian cities. Simultaneously, this attitude to the city is not automatically transferred to the locally originated politicians; on the contrary, we see a steady desire to distance from them as well as from the associated changes in the urban landscape.

\section{Conclusions}

Modern urban identity in Vinnytsia has significantly transformed during post-Soviet period. Nowadays it is gradually shaping of many patches, representing different periods of urban history and constituting together a comprehensive mosaic (including senses associated with the Soviet era that recede into the background but do not completely disappear). This gives grounds for talking about the inclusive model of urban identity formation. At the same time, the list of main urban symbols and representations about the city remains relatively constant, indicating a stable core of identity, which is based around basic things such as the city's location in the historic region, key local physiographic and cultural landmarks, brand personalities, etc. This core of identity is inertial and requires a great deal of effort (e.g. long popularization campaign via the media) to be changed.

We confirmed our hypothesis that identityrelated discussions in Vinnytsia are centred on the issues of leadership, Europeanization and modernization. Current situation, when the city is appreciated for "been better than the others", creates certain risks in the future due to the reduced resilience of the urban community to possible serious challenges, as the state of constant prosperity and leadership cannot last forever. Therefore, if a city finds itself in a difficult economic situation and loses informal state support, the public euphoria may quickly disappear, which may in turn cause negative social and economic processes. However, the issue of modernization, including aggressive commercialization within the historical areas, is the most crucial and splitting public opinion right now. On 
the one hand, modernization of urban space receives public approvals, since it is consistent with the idea of progress; on the other, it destroys the uniqueness of urban space as a basis for traditional urban identity.

The survey confirmed that industry is not any more considered as an essential element of urban identity, although is still treated as an important component of the local economy. Inhabitants feel a strong need in comfortable urban environment rather than in political/ideological symbols, they seek for human-friendly, aesthetic, safe, both morphologically and functionally diversified urban space, providing high quality of life for the locals and attractiveness for the tourists. Also, we observe pronounced shift to the local and regional values, although the connection with the national identity remains important.

Thus, local identity may be considered as one of the key factors determining the perception of the urban space transformation. This suggests that developed identity makes urban landscape more resilient to the possible aggressive changes. The success of identity transformation is largely defined by the possibility to painlessly combine new senses of place with the already existing. The public assessment of urban space transformation is also affected by coverage by local media, intensity and consistency of communication between urban administration, local cultural elites, public activists and the ordinary citizens, as well as by the moral and ethical assessment of the individuals involved in the particular transformation.

Acknowledgement: This research was carried out as a pre-study in the framework of international research project "TRIPAR Shifting Paradigms - Towards participatory urban planning", financed by the Volkswagen foundation.

\section{REFERENCES}

Adams, J.S. 2008. Monumentality in urban design: The case of Russia. Eurasian Geography and Economics 49. (3): 280-303.

Adler, N. 2005. The future of the Soviet past remains unpredictable: the resurrection of Stalinist symbols amidst the exhumation of mass graves. Europe - Asia Studies 57. 1093-1119.

Agboola, O.P. 2017. The influence of open space utilization on residents' attachment with community: A case study of rural market square in southwest Nigeria. Archnet-IJAR 11. (1): 44-66.

Aleksandravičius, E. 2006. Post-communist transition: The case of two Lithuanian capital cities. International Review of Sociology 16. (2): 347-360.

Azaryahu, M. and Foote, K.E. 2008. Historical space as narrative medium: On the configuration of spatial narratives of time at historical sites. GeoJournal 73. (3): 179-194.

BARIS, M.E., UCKAC, L. and Uslu, A. 2009. Exploring public perception of urban identity: The case of Ankara, Turkey. African Journal of Agricultural Research 4. (8): 724-735.

Bater, J.H., Amelin, V.N. and Degtyarev, A.A. 1998. Market reform and the central city: Moscow revisited. Post-Soviet Geography and Economics 39. (1): 1-18.

Bitusikova, A. 1998. Transformations of a city centre in the light of ideologies: the case of Banská Bystrica, Slovakia. International Journal of Urban and Regional Research 22. 614-22.

Bornberg, R. 2008. Identity by spatial design. Urban Design International 13. 182-200.

Boros, L., Fabula, Sz., Horváth, D. and Kovács, Z. 2016. Urban diversity and the production of public space in Budapest. Hungarian Geographical Bulletin 65. (3): 209-224.

Burch, S. and Smith, D.J. 2007. Empty spaces and the value of symbols: Estonia's 'war of monuments' from another angle. Europe - Asia Studies 59. (6): 913-936.

Coles, T. 2003. Urban tourism, place promotion and economic restructuring: the case of post-socialist Leipzig. Tourism Geographies 5. 190-219.

Crowley, D. 2003. Warsaw. London, Reaktion Books.

CzarniawsKa, B. 2002. Remembering while forgetting: the role of automorphism in city management in Warsaw. Public Administration Review 62. 163-173.

CzepczyŃski, M. and Soovëli-Sepping, H. 2006. From sacrum to profanum: reinterpretation of communist places of power in Baltic cities. Journal of Baltic Studies 47. (2): 239-255.

Diener, A.C. and Hagen, J. 2013. From socialist to post-socialist cities: Narrating the nation through urban space. Nationalities Papers 41. (4): 487-514.

Dingsdale, A. 1999. Budapest's built environment in transition. GeoJournal 49. (1): 63-78.

Forest, B. 2002. Unraveling the threads of history: Soviet-era monuments and post-Soviet national identity in Moscow. Annals of the Association of American Geographers 92. (3): 524-547.

Gospodini, A. 2004. Urban morphology and place identity in European cities: built heritage and innovative design. Journal of Urban Design 9. 225-248. 
GRIFFITHS, R. 1998. Making sameness: place marketing and the new urban entrepreneurialism. In Cities, economic competition and urban policy. Ed.: OATLEY, N., London, Chapman, 41-57.

Grodach, C. 2002. Reconstituting identity and history in post-war Mostar, Bosnia-Herzegovina. City 6. 61-82.

Gubar, O. and Herlihy, P. 2005. The persuasive power of the Odessa myth. Paper presented at the conference 'Cities after the Fall: European Integration and Urban History' (Mar.), Harvard University, USA. Available at: http://www.fas.harvard.edu/ ces-lib/ docs

Hackmann, J. 2005. Post-communist Tallinn: great architecture for a small nation. Paper presented at the conference 'Cities after the Fall: European Integration and Urban History' (Mar.), Harvard University, USA. Available at: http://www.fas. harvard.edu/ ces-lib/docs

Haskins, E.V. 2009. Russia's post-communist past: the cathedral of Christ the Savior and the reimagining of national identity. History and Memory 21. (1): 25-62.

Hein, C. 2012. Spaces of identity in East European cities. Journal of Urban History 38. (2): 372-378.

Hughes, H., Allen, D. and Wasik, D. 2003. European capital of culture and its significance for tourism and culture: the case of Krakow 2000. International Journal of Arts Management 5. 12-23.

InsCh, A. and Florek, M. 2010. Place satisfaction of city residents: findings and implications for city branding. In Towards Effective Place Brand Management: Branding European Cities and Regions. Eds.: Ashworth, G. and Kavaratzis, M., Cheltenham, Edward Elgar Publishing, 191-204.

JANSEN, S. 2001. The streets of Beograd. Urban space and protest identities in Serbia. Political Geography 20. (1): 35-55.

Karaman, A. 2001. Defining the regional identity: conceptual parameter of urban morphology. Journal of Research in Architecture E Planning 1. 70-88.

Kavaratzis, M. and Ashworth, G.J. 2005. City branding: an effective assertion of identity or a transitory marketing trick? Tijdschrift voor Economische en Sociale Geografie 96. (5): 506-514.

Kavaratzis, M. and Нatch, M.J. 2013. The dynamics of place brands: an identity-based approach to place branding theory. Marketing Theory 13. (1): 69-86.

Krylov, M.P. 2010. Regional identity of the European Russia population. Moscow, Novyi Khronograf. (in Russian)

Madsen, H. 1992. Place marketing in Liverpool: a review. International Journal of Urban and Regional Research 16. 633-640.

McNeill, D. and Tewdwr-Jones, M. 2002. Architecture, banal nationalism and re-territorialization. International Journal of Urban and Regional Research 27. 738-743.
Melnychuk, A., Gnatiuk, O. and Rastvorova, M. 2013. Territorial identity of the population of Ukraine: impact on spatial transformations. Kyiv Geographic Almanac 8. 170-175.

Mohapatra, B. and RazaK, A. 2013. Place attachment and participation in management of neighbourhood green space: a place-based community management. International Journal of Sustainable Society 5. (3): 266-283.

Molnár, V. 2013. Building the State. Architecture, Politics, and State Formation in Post-War Central Europe. London, Routledge.

Noworol, A. 1997. Strategią rozwoju Krakowa (Krakow development strategy). In Marketing Teritorialny. Strategia wyzwania dla miast i regionov. Ed.: DornANSKI, T., Łódź, University of Lodz, 132-138.

ОктАY, D. 1998. Urban spatial patterns and local identity: evaluations in a cypriot town. Open House International 23. (3): 17-23.

Октау, D. and Bala, H.A. 2015. A holistic research approach to measuring urban identity: findings from Girne (Kyrenia) area study. Archnet-IJAR 9. (2): 201-215.

PADDISON, R. 1993. City marketing, image reconstruction and urban regeneration. Urban Studies 30. 339-350.

PAP, Á. 2014. The relationship between the built cultural heritage and the local identity - actor-centred geographical analysis based on Budapest case studies. Theses of the PhD dissertation. Szeged, University of Szeged.

Petro, N.N. 2005. Old Russia's new city: Novgorod the great as a political model. Paper presented at the conference 'Cities after the Fall: European Integration and Urban History' (Mar.), Harvard University, USA. Available at: http://www.fas.harvard.edu/ ces-lib/docs

QuALLs, K.D. 2009. Today's travel through Sevastopol's past: post-communist continuity in a 'Ukrainian' cityscape. In The Cities after Fall of Communism: Reshaping Cultural Landscapes and European Identity. Ed.: Czaplicka, J., Gelazis, N. and Ruble, B.A., Washington DC, Woodrow Wilson Center Press, 167-193.

Rewakowicz, M.G. 2010. Geography matters: Regionalism and identities in contemporary Ukrainian prose. Canadian-American Slavic Studies 44. (1-2): 82-101.

Rius-Ulldemolins, J. and Jiménez, L.P. 2016. Cultura, transformación urbana y empoderamiento ciudadano frente a la gentrificación: Comparación entre el caso de Getsemaní (Cartagena de Indias) y el Raval (Barcelona). (Culture, urban transformation and civic empowerment in front of gentrification: comparison of the cases of Getsemani [Cartagena de Indias] and el Raval [Barcelona]). EURE (Santiago) 42. (126): 97-122.

Roșu, L. 2015. The urban transformations of a post-socialist city centre. The socialist relicts and current identity of Iași historical city centre. Lucrările Seminarului Geografic 'Dimitrie Cantemir' 40. (1): 159-170. 
SABAN ÖKESLI, D. and GürÇINAR, Y. 2012. An investigation of urban image and identity. Findings from Adana. Ç.Ü. Sosyal Bilimler Enstitüsü Dergisi 21. (1): 37-52.

Semian, M. and Nováček, A. 2017. The reinterpretation of histories in identities of newly established regions: The case of Local Action Groups in Czechia. Hungarian Geographical Bulletin 66. (4): 307-319.

Short, J.R., Benton, M., Buce, W.V. and Walton, J. 1993. Reconstructing the image of industrial city. Annals of Association of American Geographers 88. 207-224.

StOBART, J. 2004. Building and urban identity. Cultural space and civic boosterism in a 'new' industrial town: Burslem. Social History 29. 1761-1911.

Stober, D. and CAvrić, B. 2014. Dynamics and aesthetics of urban change in post-socialist Osijek, Croatia. International Journal of Contemporary Architecture "The New ARCH" 1. (2): 84-92.

SÝKORA, L. 2009. Post-socialist cities. In International Encyclopedia of Human Geography. Ed.: Kiтchin, R. and Thrift, N., Oxford, Elsevier, 387-395.

Ter-Ghazaryan, D.K. 2013. "Civilizing the city center": Symbolic spaces and narratives of the nation in Yerevan's post-Soviet landscape. Nationalities Papers 41. (4): 570-589.

VAN DER LUGT, R. 2013. Is the fostering of an urban identity through a city's past becoming history? Master Thesis in Human Geography. Nijmegen, Radboud University Nijmegen.

Volcic, Z. 2005. Belgrade vs. Serbia: spatial reconfigurations of belonging. Journal of Ethnic and Migration Studies 31. 639-658.
Waskiewicz, J. and Bogacz, T. 1997. Strategią rozwoju miasta Wrocławia - zalozenia, cele, programy realizacyjne (Wroclaw city development strategy - grounds, tasks and programs to realize). In Marketing Teritorialny. Strategia wyzwania dla miast i regionov. Ed.: Dornanski, T., Łódź, University of Lodz, 139-145.

WiLKInson, S. 1992. Towards a new city? A case study of image-improvement initiatives in Newcastle upon Tyne. In Rebuilding the City: Property Led Urban Regeneration. Ed.: Healey, P., Davoudi, S. and O'Toole, M., London, E \& FN Spon, 174-192.

Young, C. and KaCZMAReK, S. 1999. Changing the perception of the post-socialist city: place promotion and imagery in Łódź, Poland. Geographical Journal 165. (2): 183-191.

Young, C. and KACZMAREK, S. 2008. The socialist past and post-socialist urban identity in Central and Eastern Europe. The case of Łódź, Poland. European Urban and Regional Studies 15. (1): 53-70.

Young, C. and Lever, J. 1997. Place promotion, economic location and consumption of the city image. Tijdschrift voor Economische en Sociale Geografie 88. 332-341.

Young, C. and Light, D. 2001. Place, national identity and post-socialist transformations: an introduction. Political Geography 20. (8): 941-955.

ZeChenter, K. 2015. The repositioning of post-socialist narratives of Nowa Huta and Dunaújváros. Revue des Études Slaves 86. (1-2): 141-156. 